\title{
The impact of climatic factors on animal health (Missan province as a model)
}

\author{
Prof. Dr. Kadhim Ebadi Hammadi Al-Jasim \\ Department of Geography, Collage of Education. \\ University of Missan, Iraq \\ Corresponding author: drkad955@uomisan.edu.iq \\ drkad955@gmail.com
}

\begin{abstract}
Combined climatic elements influence directly and indirectly the animal's health by influencing the provision of green (artificial pasture) and artificial feed sources (feed and concentrated feed). The rise in temperature above the natural limit leads to the destruction of large numbers of animal wealth and the lack of their production due to the thermal stress that sometimes leads to the destruction of livestock and the death of poultry, as it affects the reproductive capacity of many animals due to the lack of sexual desire and the sperm sperm for males, which caused a decrease in reproduction and is reflected This is due to the quantities of production due to their low numbers and Missan province. The temperatures are suitable for animal husbandry and have little effect on their health. Relative humidity reduces the quantities of animal production by creating an environmental atmosphere to embrace some animals, pathogens, insects, and parasites that infect livestock with many diseases leading to their destruction. Wind affects the process of harboring animals and the quality of building barns that protect them from the heat of the midday sun in the first place. Missan province is the studied model, as it was affected by the set of factors referred to, which led to a variation in the geographical distribution in most parts of the province.
\end{abstract}

Keywords: Thermal load, heat balance, heat stress, cooling efficiency.

\section{Introduction}

The environment affects animal health through its external factors and its effects on the health and life of the animal and its growth and development and the amount of production and the impact directly or indirectly, and sometimes this effect through the interaction of environmental factors with each other.
Climate factors are one of these influences on animal health, so many scientists have been interested in studying these influences, especially climate scientists, environment, veterinarians, biologists, livestock and others in the study of climatic factors because of their great importance in the development of animal production, and to reduce the climatic conditions facing development Raising livestock and reducing its effects through the 
establishment of suitable climatic conditions for animal husbandry within the barns.

Aim of the Study

The aim of the study is to analyze the geographical factors, especially the climatic factors through their direct impact on livestock breeding and the extent of the negative effects on animal health.

\section{Analytical Methodology}

The analytical methodology was used to clarify the effect of climatic factors on animal health and applied to the animals of Missan province by adopting climatic mathematical equations that have a direct impact on animal comfort such as heat stress equation.

\section{Research Problem}

Research problem was limited to give an answer to the following questions:-

1- Is animal health affected by the degree of solar radiation in Missan province?

2 - Does sunlight affect the degree of animal growth and reproduction in the province?

3 - Does the temperature variation affect the nature and shape of the animal?

4 - Is the rain and relative humidity have a significant role in the way the animal lives within the barns?

5 - Does the speed of the wind affect the increasing incidence of diseases and the speed of their spread?

\section{Research Hypothesis}

Through the questions posed in the research problem can be answered according to the following research hypotheses

1- Animal health in Missan province is affected by varying degrees of solar radiation.

2 - Sunlight has a significant impact on the degree of growth of the animal and the nature of reproduction.

3 - The temperature has a great impact on the shape of the animal and the quality of hair and wool on his body.

4. The amount of rain and relative humidity affect how animals live in the barns.
5- The speed of the wind significant impact on the transfer of animal diseases within the barns and the speed of their spread.

\section{Research Importance}

The importance of this study is to address the geographical factors affecting animal health, especially climatic factors through its direct and indirect impact on livestock breeding in Missan province and the extent of the negative effects on animal health and growth.

\section{Research Methodology}

The research relied on the systemic approach in studying climatic factors and the extent of their impact on animal health, as well as the regional approach and field study when obtaining data from official departments is low, and the province has fewer such studies at the level of geography ,In addition, climate mathematical equations have been adopted that have a direct impact on animal comfort, such as the heat stress equation .

\section{Research Structure}

The study focused on the study of the main climatic factors affecting animal health, which were the study of solar radiation, temperature, rainfall, relative humidity and wind speed, as well as some factors related to the effects of climatic elements on animal health. Have an impact on determining the type of climate prevailing in any geographical area.

To study these climatic factors and their environmental effects on animal health, they must be defined, which is the set of elements that express the state of the atmosphere over a variable period of time in their impact on animal health, which varies from place to place depending on the factors indicated above.

In this study, we will focus on the most important climatic factors in Missan Province, which have the greatest impact on animal health, the most important of which are (solar radiation, temperature, relative humidity, wind movement), and the effect of these factors can be summarized separately. 
In the present study, we focused on Missan province as a model for studying the impact of climate factors on animal health.

The province of Missan is located in the southeastern part of Iraq bordered to the north by Wasit province, from the west by Dhi Qar province, from the south by the province of Basrah and from the east by the Islamic Republic of Iran. Its astronomical location is located between the galleries of 15, 46, 30 and 47 North and longitude 30, 46 - 30, 47 East (Map 1).

The province of Missan has a large animal wealth represented by livestock animals in the main class (sheep, cows, goats and buffalo) in addition to large numbers of poultry (Table 1, Map 2).

Directorate of Agriculture Missan - Planning and follow-up, agricultural statistics unpublished data.

\section{1- Solar Radiation}

Solar radiation is one of the most climatic elements affecting the health of the animal and its effect is directly and indirectly, The direct effect is the arrival of the sun's rays to the earth after passing through a group of effects that reflect, absorb and disperse part of the solar radiation, and the section that reaches the surface of the earth and after reflection becomes a factor Directly affecting on animal health.

Table (1): Preparing the livestock resources in Missan province for the year 2018 (number 1000)

\begin{tabular}{|c|c|c|c|c|c|}
\hline Type of Animal & Sheep & Cowes & Goats & Buffalo & Poultry \\
\hline No & 429.2 & 150.8 & 28.3 & 27.4 & 325.7 \\
\hline
\end{tabular}

Source: Directorate of Agriculture Missan - Planning and follow-up, agricultural statistics unpublished data.

Map 1: Geographical location of Missan province

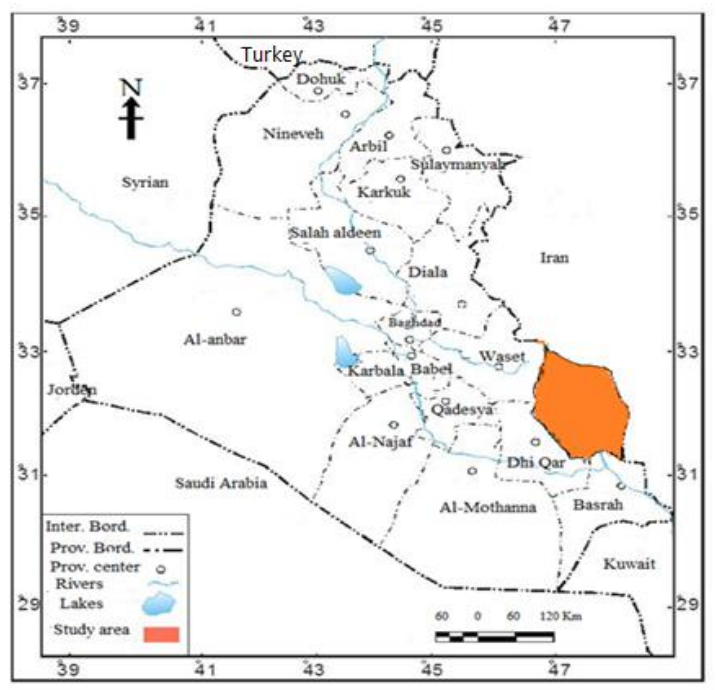

Source : Map of the General Authority for Survey - Map of Missan province .

Radiation begins for bodies whose temperature rises above zero percentile. From these bodies are the bodies of animal wealth that vary in the colors of their skin and hair. The radiation is through the exposure of their bodies to solar radiation during the daytime period, which 
part of it sometimes loses to the air medium that comes into contact with the animal's body in the case of a high degree Its body temperature compared to the heat of the surrounding air medium.

The acquisition of animal bodies by the sun's rays varies from one place to another and from one animal to another according to the environment in which they live, in addition to the variation in the color of its skin and hair and the duration of exposure of the sun to sunlight, as well as the variation in the astronomical location in which the animal lives to the degree of variation of the angle of sunlight fall within the width circle, As the type of falling radiation.

Radiation begins for bodies whose temperature rises above zero percentile. From these bodies are the bodies of animal wealth that vary in the colors of their skin and hair.

Map 2: Geographical distribution of livestock in Missan province for 2018.

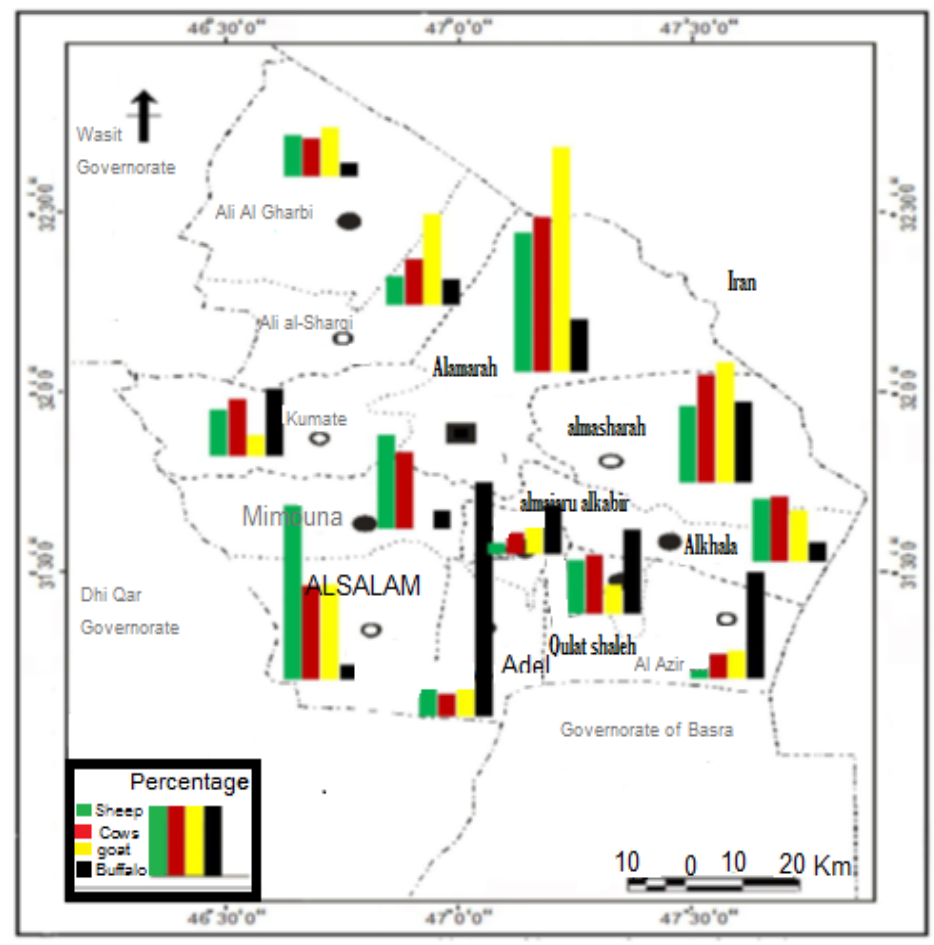

\footnotetext{
Source: From the work of the researcher relying on :

a - data of the Directorate of Agriculture Missan province - Planning and follow-up
}

b - Map of the General Authority for Survey - Map of Missan Governorate.

The radiation is through the exposure of their bodies to solar radiation during the daytime period, which part of it sometimes loses to the air medium that comes into contact with the animal's body in the case of a high degree Its body temperature compared to the heat of the surrounding air medium.

The acquisition of animal bodies by the sun's rays varies from one place to another and from one animal to another according to the 
environment in which they live, in addition to the variation in the color of its skin and hair and the duration of exposure of the sun to sunlight, as well as the variation in the astronomical location in which the animal lives to the degree of variation of the angle of sunlight fall within the width circle, As the type of falling radiation differs on the place and its length, which is represented by long or short wavelengths, or ultraviolet and infrared, as the length of the first waves (0.01 microns) and the second (1 micron) respectively, and the effect of ultraviolet waves on the bodies of animals while it reaches The effect of short waves on the dermis and below it.

Solar radiation has a clear role in the direct impact on animal health, especially when it increases its quantity. It affects the skin of animals and the mucous membranes, causing the animals to suffer sunburn, and more to the diseases of photosynthesis. The effect increases when increased radiation increases temperature. The burden of heat.

It is the environmental conditions, such as temperature, wind and air humidity, which affect our bodies and our general sense, including livestock, and vary from one environment to another and from one animal to another depending on the degree of tolerance of the animal to climatic conditions in the open and places of production, and measured through the following equation

It is possible to determine the exposure of agricultural animals to thermal stress and the equation

$\mathrm{THi}=\mathrm{db}-(0.55-0.55 \mathrm{RH})$

or the modified equation (db-0.33-0.31RH) (db-14.4 where $\mathrm{db}=$ dry heat temperature)

$(\mathrm{RH}=$ humidity ratio $($ Jasim 2015)( www.forum.stop55.com).

On the body of the animal and this is reflected on the performance of the animal physiologically and thus decrease the production of milk, meat and eggs because of lack of appetite to eat fodder in addition to accompanying idle and laziness and desire to sleep and stagnation for poultry.

The animal can adapt to this climate factor affecting its health through the thickness of the skin and hair color and density (scalp), as this is very necessary adaptation to animals living in the cold and warm, it was found that the scalp body of great importance affecting the health of animals where it is acquired animal temperature, especially during the winter in the cold areas and during the summer in the warm areas.

As it is white color and the most transparent of the colors reflect the radiation of the sun, In warm areas, it reduces solar radiation reaching the body of the animal, while black and dark color are more suitable for animals of the cold zone as a color that absorbs the solar radiation, which helps the body of the animal to provide warmth and raise the temperature of the body, The white color of animal skin and bird feathers reflected most visible solar rays with wavelengths ranging from 0.3 to 0.8 microns, while less than short-wave ultraviolet rays wavelengths of 0.8 to 2.5 microns) Otherwise the color is black or dark (Mari , 1996 ) .

It was found that the yellow color of the body's cornea is very much related to the absorption and reflection of solar radiation. Africander and Zebu Cows absorb about $45 \%$ of the radiation and reflect $15 \%$ of the body, while the Aberdeen cows absorb $89 \%$ of the radiation and reflect only about $5 \%$ of the radiation and this is due to the hair color and degree of brightness and density in addition to the spread of melanin in the skin.

The increase in solar radiation affects the spread of many animal diseases that reduce the production of the animal and affect his health. These diseases are congenital swelling. The spread of this disease in the cows of the warm zone, especially Friesian cows, which caused a shortage of milk and therefore reflected on the amount of production. 
By observing the number of hours of solar radiation in Missan province, as shown in Table (2).

The overall average is 8.8 hours per day. Therefore, the province climate is suitable for animal husbandry and has little impact on animal health except for some days of the year, daily to 11.3 hours during June and July. The effect of this climate element can be avoided or reduced to animal health by setting up tree-shaded sheds and providing shade for animals affected by increasing its quantity.

Animal pens or shelters may be set up, especially at noon, covered with aluminum and reflective materials to reduce solar radiation, and can be followed by new methods of grazing times were to be in the early morning or evening or night of the moon, In both cases, the solar radiation is few and makes up for the lack of grazing period by giving animals concentrates.

\section{The Relationship between Sunlight and Animal Health}

Sunlight plays a large and important role in many animal life and encourages reproduction and mating especially during a limited period of the year, varies from one animal to another and from one region to another, Some studies and scientific experiments have shown that sexual desire and period of euphoria in the cold and distant animals of the region (Long day) and short winter are suitable for mating, while in the vicinity of the equator during the spring and autumn of moderate light, and in the province of Missan, The number of light hours during the summer to 11.3 hours a day during the month of June and July and less during the winter season, the lowest in the month of January and 6.5 hours a day.

Table 2: Monthly and annual averages of climate elements in Missan province for 2018

\begin{tabular}{|l|c|c|c|c|c|}
\hline \multicolumn{1}{|c|}{$\begin{array}{c}\text { Months of the } \\
\text { year }\end{array}$} & Solar radiation & Temperature & Rainfall & Relative humidity & Wind speed \\
\hline & $(\mathrm{h} / \mathrm{d})$ & $\left(\mathrm{c}^{\mathrm{o}}\right)$ & $(\mathrm{mm})$ & $(\%)$ & $(\mathrm{m} / \mathrm{s})$ \\
\hline January & 6.5 & 11.5 & 35.6 & 70.6 & 2.9 \\
\hline February & 7.4 & 13.7 & 23 & 63.5 & 3.1 \\
\hline March & 7.9 & 18 & 33 & 59 & 3.7 \\
\hline April & 8.5 & 24.2 & 15.4 & 44.4 & 4 \\
\hline May & 7.9 & 30.2 & 4 & 33 & 4.2 \\
\hline June & 11.3 & 34.3 & 0 & 28.3 & 6 \\
\hline July & 11.3 & 36.5 & 0 & 26.2 & 5.7 \\
\hline August & 11.1 & 35.6 & 0 & 28.1 & 5.2 \\
\hline September & 10.2 & 32.1 & 0 & 30 & 4 \\
\hline October & 9.6 & 26.2 & 6.5 & 42.3 & 3.4 \\
\hline November & 7.4 & 16.9 & 22.2 & 55 & 3 \\
\hline December & 6.9 & 12.9 & 33 & 70.2 & 2.8 \\
\hline Total & 106 & 292.1 & 172.7 & 550.6 & 48 \\
\hline General Average & 8.8 & 24.34 & & 45.88 & 4 \\
\hline
\end{tabular}

Ministry of Transport and Communications - General Authority for Meteorology - unpublished data. 
The effect of light on the reproductive processes in sheep is more than the cows, where it affects the pituitary gland in sheep and the lack of influence in cows, where the correlation of cattle reproduction with light period (Noh, www.gcsar.gov.sy).

The light also affects the activity and vitality of poultry, as it helps in the rapid consumption of food as well as its contribution to the formation of vitamin (D) cholesterol in the fats located under the skin of the animal, Which helps to build the skeletons of all animals and birds, and helps light on the disinfection of bodies Many animal skins and bird feathers from pathogens and microbes die and some die by exposing the animal to sunlight during the daytime, Where ultraviolet radiation helps destroy microbes ( Jindal, 2001).

Sunlight helps the poultry to activate the eye's nerve and stimulate the frontal lobe of the pituitary gland, which develops its reproductive system, so that the light is important to it, especially at the beginning of growth, which requires during this period to 24 hours daily light.

This is why poultry breeders put light lamps in their pens during the days The first period of her life to get enough light and continuous during the day and night for the permanence of growth and then decrease this period gradually by 20 minutes every day starting from the first week of age to up to 12 hours a day during the first 20 weeks of life (Interview, 2018).

The light is dim in In order to reduce the phenomenon of predation and feather feathers in poultry (Feather Picking) as well as increased consumption of food in young poultry and chicks.

One of the researchers said that light is one of the factors affecting animal health, which helps in the migration of animals in general, such as aquatic turtles, crustaceans and wild birds and long distances, which has a clear relationship in the process of mating between wild birds and was one of the causes of migration of birds across continents, Long light (the length of the day) stimulates the sexual glands that increase throughout the day (Potter, www.llpdigital.usembassy.gov).

\section{2- Temperature}

Which is the heat resulting from solar radiation reflected from the surface of the earth, which surrounds the body of the animal and affects the health and growth, negatively or positively, including quantities of production of milk, meat, eggs and other animal products, animal farm animals of all types of livestock (Homotherms) Which has the ability to maintain physiological temperature and physiological adjustment in the case of high or low temperature of the surrounding atmosphere, which is known as environmental thermal balance (Thermal balance).

This effect is direct in the case of heat exchange between the animal's body and the surrounding thermal environment. The effect is indirect if the animal's body is affected only by the surrounding thermal environment.

The energy lost by the animal's body is known to occur from several main exits, In addition to radiation sweating, evaporation, contact, contact, etc, as shown in Figure (1), which we will clarify as follows: -

\section{a- Radiation Solar}

The body of the animal loses its temperature to the surrounding medium by radiation. This process occurs when the body temperature of the animal is higher than the temperature of the surrounding environment in which it lives. 
Figure 1: Heat balance of temperature sources

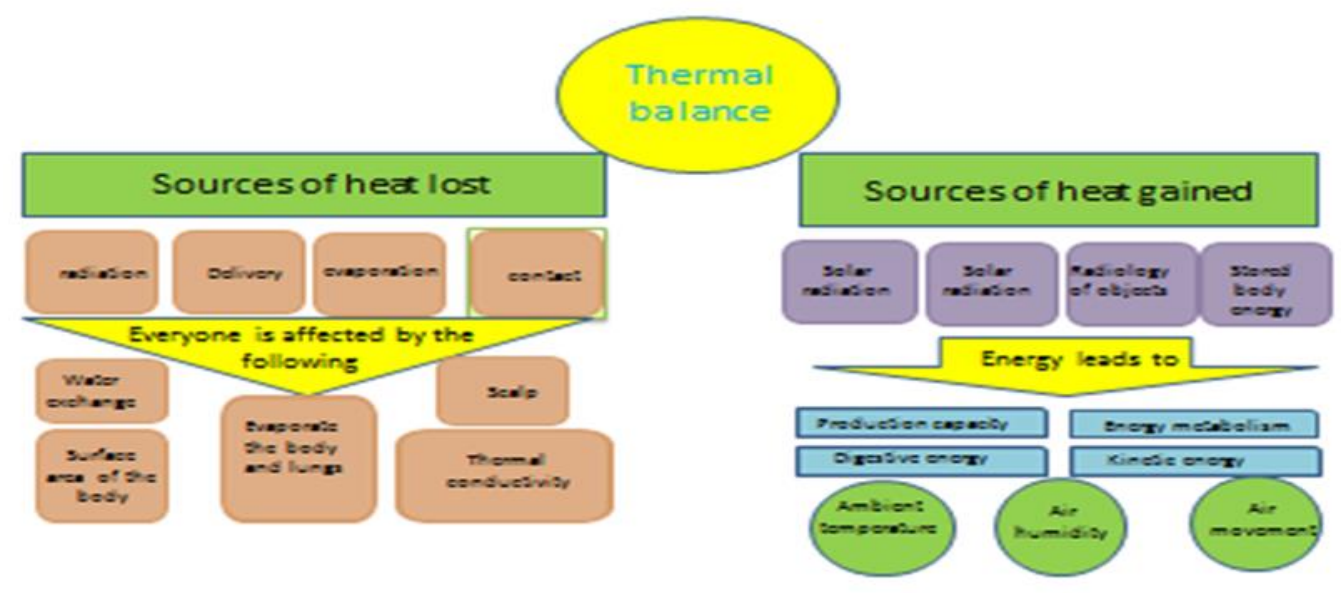

This is the case in cold areas where temperatures are low Which reach less than 30 ${ }^{\circ} \mathrm{c}$ and diminish this situation whenever the temperature is more than $35^{\circ} \mathrm{c}$ This is what happens in the hot seasons, and depends on the loss of temperature on the following factors:-

a - The surface area of the animal's body.

b - Self-capacity in thermal radiation.

c- The position and behavior of the animal and depends on the number of animals inside the barn where it is inversely proportional to the less radiation when increasing the number and increase when reduced.

\section{b- Convection}

This is the process of transferring temperatures through the moving medium from warm objects to the less warm medium. This also depends on the number of animals inside the dwelling, the temperature separation, the ambient temperature of the animal, and the movement of air inside the barn, which affects the degree of thermal loss of the animal's body, Poultry and lead to the occurrence of many animal diseases, especially chilling diseases.

\section{c- Conduction}

The animal loses the temperature of its body to the surrounding medium by direct contact with the cold surfaces and the loss is great during the cold season. Therefore, the animal breeders have to put a thick straw mattress in the barn floor to reduce the soil moisture and keep the body temperature from loss.

\section{d. Evaporation}

The temperature of the animal's body is lost through the process of evaporation of body fluids through the lungs and the animal. This method of loss of temperature, especially during the hot summer, through the process of sweating is lost temperature, where zoologists estimated that more than $80 \%$ The water is lost from the body of the senses through sweating, and the animals of horses in the forefront of animal wealth and the activity of the thyroid glands in the body, and then followed by animals for the pores spread on the skin, followed by animals and camels cows and sheep and the least sweating cats animals, and lack of pores in the skin August and poultry , but In dogs, the sweating rate is 30 times per minute and more in poultry, due to the lack of thyroid glands in these animals .

So get rid of the temperature process hyperventilating process (Panting) where the thermal equilibrium process.

The number of thyroid glands in the animal's body varies from one animal to another and within the animal species as well, For example The cows and buffaloes, European cows living in cold areas have fewer thyroid glands in their 
bodies compared to those in warm regions that have a high number of thyroid glands Zippo for continuous exposure to sweating, reaching the thyroid glands in the bodies of European cows to $40 \mathrm{~cm}^{r} / \mathrm{m}^{r}$.

The cows in the Tropical region to $480 \mathrm{~cm}^{2} /$ $\mathrm{m}^{2}$ and less than these glands in buffalo animals, which made them live near water resources such as rivers and the marshes where a long period of her life is immersed in water especially during the hot summer.

\section{Relationship between Temperature and Animal Health}

Temperature is one of the most climatic factors affecting animal health, especially in tropical and subtropical hot lands.

The effect is limited when the heat burden has limited effect on animal productivity. The process of heat balance and regulating the temperature of the body with the temperature of the medium in which the animal lives is appropriate, where the temperature of the thermocouple is close to the temperature of the body of the animal, this does not represent heat on the animal's body and called this Situation Comfort.

And determine this degree in the warm areas between $16-27{ }^{\circ} \mathrm{c}$ and in the cold areas between $1-16^{\circ} \mathrm{c}$. If the temperature exceeds the rate mentioned, the effect is negative on the health of the animal including:-

a- The height of the body of the animal from the thermal medium.

b - Lack of animal appetite for food.

c- Increasing water consumption.

d- Low growth rate.

e- Decrease the amount of milk, meat and eggs production.

f- The weakness of the animal and disorder of behavior, so that it becomes lazy, inactive, avoids sunlight, and increases sleep for livestock and poultry for poultry.

These characteristics can be observed when moving animals from temperate to cold areas where the temperature between the two regions varies.

This is the case before adaptation to the animal habitat, and this changes after adaptation Such situations occur before the process of adaptation to the medium in which animals live, as these situations change after the process of acclimatization and adaptation .

Some field studies have been proven that The thermal environment in which animals live at the temperature of their bodies, they affect their health through a change in physiological processes such as fertility, sexual desire, length of pregnancy and survival of the fetus in the uterus of the female, in addition to increasing the problem of childbirth to cows, and this extends to the decomposition in the male and male areas of sheep, especially the Marino type, and the injury of some to temporary sterility, especially if the temperature rises above $35^{\circ} \mathrm{c}$ long and Gesture (Ismail, 1982).

In poultry, the high temperature affects the lives of chick chicks, especially in small ages. If the temperature rises above $27 \mathrm{~m}^{\circ}$, it is affected by the lack of egg production, size, color and thickness of the shell. If it reaches more than $29^{\circ} \mathrm{c}$, poultry are subject to lack of growth, The optimal temperature for poultry is $25^{\circ} \mathrm{c}$ and for one day and decreases to less than that when the age increases to $16^{\circ} \mathrm{c}$ at the age of 6 weeks, and the temperature in the chicken breeds differ in the production of eggs (Jasim, 2015) as shown in Table (3). 
Table 3: The relationship between temperature $\left(\mathrm{c}^{\mathrm{o}}\right)$ and age of the poultry in the incubation period

\begin{tabular}{|c|c|c|c|c|c|c|c|}
\hline Age (week) & The first & second & third & fourth & Fifth & Sixth & Seventh \\
\hline begging week & 34 & 33 & 29 & 27 & 25 & 23 & 21 \\
\hline weekend & 32 & 30 & 28 & 26 & 24 & 22 & 22 \\
\hline
\end{tabular}

kadhim Abadi Al-Jasim - Geography of Agriculture - Amman, 2015 - p 330

In order to preserve animal health from high temperatures, many animal breeders follow the sound scientific methods of prevention:-

a - Follow good harboring systems for animals inside the pens, the smaller the number of animals in the barn, the better the habitat will be and the good health to take care of the numbers of small quantities compared to the large numbers in terms of providing feed, water and good bedding and veterinary care and this is reflected in the quantity and quality of production.

b - Sufficient ventilation of the barn in terms of the large number of outlets that help to renew the air and movement continued during the times of the day, the distribution of ports, including the section to enter the air and sunlight and another to get out of the air and the entry of sunlight during the day according to the movement of the sun daily.

c - Use of desert coolers or large air vents that help to move the air and switch inside the barn and this helps to accommodate a larger number of animals inside the barn, and the role of the suction is important in the process of lowering the temperature and temper the atmosphere inside the pens and change the humidity inside .

The lower of humidity in the air, the more refrigerant the desert will be able to reduce the temperature inside the hatch so that it reaches the reading of the wet thermometer, which is illustrated by the following formula :- cooling efficiency $=$ difference between reading dry and wet thermometers $\times$ humidity in the atmosphere, (For example, wet humidifiers read 23m, dry $35 \mathrm{~m}$ and humidity $82 \%$, cooling efficiency becomes 9.8 through the result of equation $=(35-23) \times(82 \div 100)$.

In many countries of the world, hot water sprayers are used through special pipes to reduce the temperature through the water evaporation process.

High air pressure in the barns can be avoided using air vents to cool the atmosphere and reduce pressure inside the barns.

$\mathrm{d}$ - Use of shading inside exposed barns, especially in rural areas devoted to raising livestock.

e - Use washing and spraying of animal bodies in order to reduce the temperature of their surface bodies and clean the pores spread over their skins, Which helps to accelerate the process of sweating and evaporation and get rid of excess high temperatures and the environment surrounding the environment, and these things make the animal live healthy and free of animal diseases, which is the animal production in larger quantities and good quality.

One of the veterinary studies of cows in the hot areas where the washing process of animals that the production of milk Up to 2.5 times compared to cows did not use the process of washing, especially during the summer heat. 
F- Cutting the hair scalp spread over the surface area of the body of an animal, which helps in the process of eliminating the temperature processes sweating and evaporation and reduce the degree of heat burden of the body of the animal.

After showing the most important general variations in temperature, we note that the province of Missan is suitable for breeding livestock in terms of availability of appropriate temperature grades in the province, as shown in Table (2) where the average temperature of $24.3 \mathrm{c}^{\circ}$ and the highest in the summer months in June $\left(35.5 \mathrm{c}^{\circ}\right)$. It is suitable for raising livestock and poultry, especially during the first few weeks of the growth of chicks, as shown in Table (3) which requires special care such as shaded barns and ventilation or air cooling using air vents.

\section{3- Relative Humidity}

Relative humidity is the amount of water vapor diffused in the air and measured by introducing a quantity of water in a special test tube in which the amount of mercury to measure the atmospheric pressure in the water is pushing the mercury down as much as the pressure of the pressure has reached the maximum point of saturation, It is used in the measurement of moisture relative to the law of Boyle based on the pressure of saturated water vapor at the dew point and normal air temperature, and is used for measuring special devices such as dry and wet hysterometer, dizziness, hair and hectograph.

The impact of relative humidity on animal health is related to the high proportion of air, especially hot air, which hinders the process of elimination of high temperatures affecting the body of the animal and the harassment of movement and the demand for food, and one biological and climatic studies indicated that the low humidity in the atmosphere, 20-80\% have little effect on animal health whether the air is cold or hot as long as the animal has the ability to adapt and adapt to the optimum temperature.

The high humidity in the air is less than the animal cannot withstand the process of heat stress, which affects the health by increasing the burden of heat, which leads to a reduction in the proportion of production to $30 \%$ as in the fattening of cattle in addition to the disease of heat stroke or heat (Heat stroke).

If the ratio rises between 80-90\% and air temperature of $45 \mathrm{c}^{\circ}$ will lead to the cessation of most of the functions of the body of the animal and may reach the situation of loss, especially at the drop of the heart, and cause high humidity and high temperature up to $30 \mathrm{~m}^{0}$ to low proportion Milk in Cows (Saleh et al., 1989).

The increase in relative humidity in the air to affect the fetus inside the eggs in artificial insulators, especially during the early stages of growth, so control of the rate of the main factors in the process of hatching where the decrease in the effect of the withdrawal of liquids in the inside of the egg, Feathers have negative effects on poultry health in their resistance to external stimuli in the environment (Marali, 1996).

Through these environmental effects of relative humidity, which is affected by the temperature of wet and dry air, the humidity in Missan province is suitable for animal husbandry and health maintenance, where we indicated beforehand that if the humidity ranged between $20-80 \%$, it does not harm the health of the animal, As shown in Table (2) between 26.2-70.6 \% are suitable for animal husbandry and do not need a lot of material costs in the case of height of Hungary ventilation space and air movement, which helps to reduce the humidity in the places of barns and haters.

As a result of the effects of rising temperatures and relative humidity in the air and in animal housing, livestock breeders should maintain their numbers within the barns and take into 
consideration the weather changes that affect their health, especially when transported from one place to another or the marketing process when selling, In the case of accumulation of waste in the floor of the dwelling and in many quantities, this disease may lead to colds and diseases when exposed to cold air during the winter, which is less resistant to animal diseases and called these cases of discomfort to the animal (Discomfort Index) :-

The evidence of the rest of the human and animal is extracted according to the following equation: $\quad(d . I=0.55 \mathrm{Td} b+0.2 \mathrm{Tdp} \div$ 17.5)

Where: d.I $=$ discomfort index,$\quad T d b=d r y$ temperature in Fahrenheit, $T d p=$ dew point in Fahrenheit.

There are also special tables to know the dew point by knowing the relative humidity and the average temperature in place.

This term is compatible with humans and animals, and is spread in hot humid days, as is the case in most parts of southern Iraq, especially Basra province, which is close to the Arabian Gulf region, the source of moisture in the air.

Some people point out that the animal's comfortable zone is the area where the animal does not need any orderly processes of body temperature. This area differs from one place to another and from one animal to another depending on the type, age, size, skin thickness and amount of hair covered.

The result of the above equation is that the comfort index of $70 \%$ means that $10 \%$ of the animal feels comfortable and if it reaches $80 \%$, all animals and humans feel comfortable, but the $75 \%$ comfort index affects some animals, such as cows with less milk At this level, cow breeders are able to build housing and comfortable barns to accommodate the animal's production of milk (Ismail, 1982).

After studying the characteristics of relative humidity and its relation to animal health, some of the effects can be summarized, which lead to many complications, the most important of which are:-

a- Low production of milk, meat and eggs.

b- The spread of many animal diseases that help the relative humidity to provide an environmental environment for its spread.

c- The increase in the number of germicidal vectors and insects affecting the health of animals such as flies, mosquitoes and others.

d. Moisturizing the skin of the animal and the scalp of the body, which are suitable environments for many insects and pathogenic bacteria such as ticks and lice, especially on the bodies of livestock.

These include the increase in the number of animals in the sheds. This leads to the rapid movement of infections among animals. Breathing leads to high humidity and the sorting of animals through water vapor. The process of exhaling, which varies from one place to another and beyond the difference in the temperature and size of the animal as shown in Table (4) and to maintain the health of the animal from the large increase in air humidity can be the following:-

Table 4: The relationship between the weight of the animal and the amount of moisture distributed .

\begin{tabular}{|c|c|c|}
\hline Type of animal & Weight $(\mathrm{kg})$ & Relative humidity $(\mathrm{g} / \mathrm{h})$ \\
\hline Calves & 135 & 200 \\
\hline Adult cattle & 4500 & 400 \\
\hline Chicken meat & 1.5 & 2.5 \\
\hline Eggs Chicen & 3 & 2.5 \\
\hline
\end{tabular}

Abdel Al-Moez Ahmed Ismail et al. (1982). Animal Health, Mosul Univ. Press: p. 32. 
a- Construction of housing in high places and far from groundwater to prevent the phenomena of leaching and gurgling from the ground.

b- Building the side walls of the concrete to reduce the leakage of water to the barns, especially in the coastal areas and the sites of the barns near the rivers.

c - Reduce the number of animals inside the barns to reduce animal congestion, which leads to reduce the amount of exhalation outside during the breathing process.

d- Continuous maintenance and cleaning of sheds to reduce the accumulation of waste, which cause many diseases and a safe haven for many pathogens and carriers such as insects and worms.

e- Good and continuous ventilation and increase the number of air openings of the barns and helps to increase the movement of air inside them rather than allowing the light and sunlight to enter into the barns and a break during the day.

f- Increasing the number of air hoods and coolers that help to rotate, purify, move and change air in animal housing, thus reducing relative humidity.

\section{4- The Wind}

Air movement is important factors affecting animal health and sustainability and continuity in animal production from the dairy, meat and egg process so is the study of this important climate component as one of the factors that provide a healthy atmosphere for the animal inside the barns and in the forefront of change in temperature, relative humidity and ventilation Housing, and through which the safety of the animal inside the barn is maintained in terms of health free from many diseases affecting livestock.

The size of the moving air inside the house varies according to the size of the area occupied by the barn, which varies from one animal to another depending on the surface area and the size and weight of the animal. It is natural for poultry accommodation to be different from that of cows and buffaloes, etc. Therefore, the size of the dwelling is highly related to the movement of wind and internal inputs for ventilation. To calculate the number of ventilation times inside the barns, the equation results can be followed and applied to estimate the amount of carbon dioxide inside the dwelling :-

$\mathrm{CO}_{2}$ is estimated by the following equation: -

$K=4+(10000(X) / a) \quad$ Where:

$\mathrm{K}=\mathrm{CO}_{2}$ concentration in the atmosphere is estimated for each (4 part per 10,000).

$a=$ the volume of air needed for each head of animals $\left(\mathrm{m}^{3}\right)$.

$X=$ the volume of $\mathrm{CO}_{2}$ externally from the animal exhalation is estimated ( $\mathrm{m} 3 / \mathrm{h}$ ).

( Ismail - 1982)

The ventilation has a clear role in influencing the health of the animal through which the temperature is adjusted, especially when it drops outside the animal's equilibrium point, the wind speed, especially during the winter, will lead to thermal insulation of the body and raise the temperature of the minimum temperature, the cold air speed does not reduce the temperature of the animal's body by evaporation, unlike the movement of hot air during the summer, which does the opposite. It increases heat stress through the process of heat transfer of external air to the animal's body by the process of contact, and lead sometimes the effect of the movement of air cold facilities to lower the temperature to the destruction of some animal wealth, including small poultry where growth stops at such thermal situations that occur during the winter and lead to considerable material losses for poultry farmers.

The rapid air movement (storms) associated with dust, sand and dust lead to the injury of a number of animals bruises and fractures and 
loss of their feathers and feathers as a result of crowding and lead to some animals falling from the top and death, in addition to shortness of breath, some of which lead to suffocation and lack of breathing and death.

In order to study the effect of air movement and wind speed, Missan province is exposed to the phenomenon of dust and sand storms, which leads to the destruction of a number of animal resources during the stages of movement between the pastures and natural habitats where the wind speed in the months of May and June to $6 \mathrm{~m} / \mathrm{S}$ affect animal health, especially livestock.

\section{Research Results}

After identifying the most important effects of climatic elements and their relation to animal health, directly or indirectly, a series of results can be found that illustrate this relationship to animal health.

a- The climatic elements combined have a direct and indirect effect on animal health by influencing the availability of feed stocks and artificial feed stocks. The situation may be rare due to climatic fluctuations and lack of rainfall, For the cultivation of fodder crops and crops dependent on their waste, such as grain crops mainly, and this is reflected in the destruction of large numbers of livestock, especially cattle and sheep in cases of scarcity of rain and the lack of natural pastures and shrinking areas planted with feed crops.

b- high temperatures from the natural limit leads to the destruction of a large number of animal resources and lack of production due to thermal stress, which sometimes lead to the destruction of livestock and mortality of poultry, and affects the reproductive capacity of many animals for lack of sexual desire and lack of sperm for males, causing the lack of reproduction This is reflected in the quantities of production of a small number and the province of Missan temperature is suitable for raising animals and have little impact on their health. c- Relative humidity reduces the quantities of animal production and indirectly within the barns by creating an environmental environment for the incubation of some animals, pathogens, insects and parasites that afflict livestock, many of the diseases leading to their destruction.

$\mathrm{d}$ - The wind speed in some seasons of the hot and cold animal health, so you need to process your accommodation through the construction of barns that protect them from the heat of the sun in the first degree.

e - The climatic fluctuations in animal resources will inevitably lead to a state of discomfort and stability within the houses and some animal breeds are vulnerable to diseases because of their weakness and lack of resistance to these bitter climatic changes, which makes their productive capacity less compared to the veterinary services and feeds so that they are economical On their breeders.

\section{Recommendations}

1- The official departments should provide agricultural credit to the livestock breeders in order to build the shelters for animals and rid them of high temperatures, especially during the hot summer season that characterizes Missan Province, This reduces the percentage of mortality and mortality for poultry, as it is one of the animals most exposed to this climate characteristic. in summer .

2- Given the exposure of animal wealth in the Missan Province to a group of animal diseases due to the influence of some climatic factors such as relative humidity that helps to create a climate favorable to the growth of fungi and bacteria, the state and veterinary institutions should pay attention to the livestock sector and establish field work and field visits to their breeding fields and work on Examination and control of diseases suffered in the province of Missan.

3- Providing artificial feed sources (diets and concentrated feed) in the vicinity of green fodder, especially in times of scarcity due to 
climatic fluctuations and less rainfall, which leads to exposure to some types of animal wealth, especially cows and sheep, for the state to follow such climatic conditions and work to Reducing animal wealth exposure to such climatic conditions.

4- Opening veterinary care centers in the administrative centers of the province (districts and districts) and not focusing on the general veterinary hospital in the district center, which sometimes leads to difficult access to it.

5- Continuous follow-up by the livestock cadres in the province, conducting continuous checks and numbering the heads of animal wealth and registering them in special records in order to know the problems facing the animal wealth

\section{Research Sources}

1- Abdel-Aleem, K. (1977). Cattle breeding and production and transfer. The Egyptian Knowledge House, Cairo, p. 32.

2- Darwish, M. Y. (1962). Meat Production, Cairo, p. 91-92.
3- Ismail, A. A. (1982). Animal Health, Mosul Univ. Press, p. 21-34.

4- Jandel, J. M. (2001). Effect of solar radiation on animals. Journal of Cows and Sheep in the Middle East, No. 32, p. 45.

5- Jasim, K. A. (2015). Geography of Agriculture, Amman - p. 297, 330.

6- Mari, M. S. (1996). Geography of Agriculture, Mosul Univ. Press, p. 363, 410.

7- Saleh, Ahmed Haj Taha, Yunus, A. D. and Rashid. M.R. (1989). Milk cattle, Mosul Univ. Press, p.166.

8- Noah, A. The impact of environmental changes on the production and reproductive performance in cattle- Research published on the website www.gcsar.gov.sy.

9- Potter, C. The impact of climate on animals and ecosystems- Manchu's research on www.llpdigital.usembassy.gov.

10- An interview conducted by the researcher with the agricultural engineer, Karim Jumaa, the owner of a poultry farm in Missan Province on 16/9/2019.

11- www.forum.stop 55.com. 


\section{تأثير العوامل المناخية على صحة الحيوان محافظة ميسان نموذجا}

\section{أ.د. كاظم عبادي حمادي الجاسم}

\section{جامعة ميسان ..كلية التربية .ققسم الجغرافية}

مستخلص. تؤثر العناصر المناخية بشكل مباشر وغير مباشر على صحة الحيوان من خلال تأثيرها على توفير

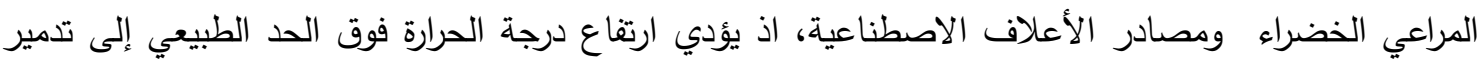

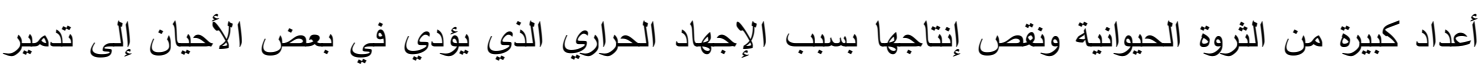

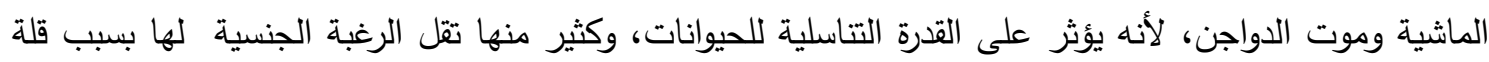

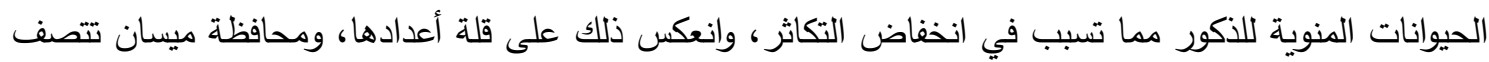
درجات الحرارة فيها وانها مناسبة لتربية الحيوانات وليس لها تأثير يذكر على صحة الثروات الحيوانية التي تعيش في معظم مناطقها. اما الرطوبة النسبية فإنها تقلل من كميات الإنتاج الحيواني من خلال خلق جو بيئي لاحتضان بعض الحيوانات ومسببات الأمراض والحشرات والطفيليات التي تصيب الماشية بالعديد من الأمراض مما يؤدي إلى تدميرها. وتؤثر الرياح على عملية إيواء الحيوانات ونوعية بناء الحظائر التي تحميها من حرارة الثمس المرتفعة بسب الرياح الحارة

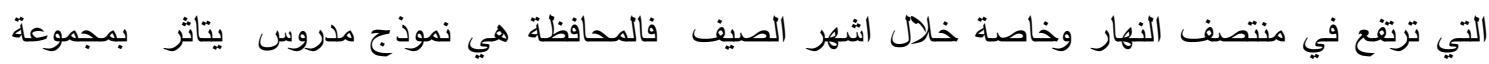
العوامل المشار إليها، الامر الذي أدى إلى تباين في التوزيع الجغرافي للثروات الحيوانية في معظم أنحاءها. الكلمات الدليلية: الحمل الحراري، التوازن الحراري، الإجهاد الحراري، كفاءة التبريد. 